\title{
無脾症候群の成績改善とその治療方針
}

\author{
中田朋宏猪 飼秋夫藤本欣史廣瀬圭一 \\ 太田 教 隆登坂 有子井出 雄二郎坂本喜三郎
}

\begin{abstract}
無脾症候群は多種多様な心奇形を合併し, 重症度の高い疾患群である. 今回, 1987 2006 年 10 月末の 過去約 20 年間に当院で初回より手術介入を行った無脾症候群連続 71 例（1987 1996 年：前期群 34 例, $1997 \sim 2006$ 年 10 月末：後期群 37 例）を検討した。前期群に有意に肺動脈弃狭窄（p=0.010）が多く, 後 期群で新生児 $(p=0.010)$, 体重 $3 \mathrm{~kg}$ 未満例 $(p=0.037)$, 肺動脈弁閉鎖 $(p=0.013)$ が多かった。全例 Fontan 手術対象で，二心室治療対象例はいなかった。前期群の累積生存率は 1 年 $52.9 \%, 5$ 年 $32.4 \%$ と不 良であり，原因として，1）右心バイパス到達までの期間が長く，房室弁逆流や長期のチアノーゼによる側 副血行路増生などの問題も絡んで, 容量負荷による心機能低下を起こしたこと，また，2）肺動脈縮窄を中 心とする肺動脈系の問題, 総肺静脈還流異常症 (TAPVC) を中心とする肺静脈系の問題が絡み合って十分 な肺区域の確保が困難であったことが考えられた。笛こで後期群で手術方針を変更し，容量負荷を回避して 心機能を保護するため，1）早期の右心バイパス手術到達，2）積極的な房室弁形成を行い，また，有効肺区 域を可能なかぎり確保するため，3）中心肺動脈領域での肺動脈形成を伴う肺血流路確保（central pulmonary artery strategy)，4）TAPVC 修復時の吻合手技の改良を行った。また，乥れらにもかかわらず肺血 流が左右不均衡で Fontan 手術到達困難とされた症例には，5）新しい中間手術：intrapulmonary-artery septation を導入した. 結果としては, 後期群の累積生存率は 1 年 $66.8 \%, 5$ 年 $53.1 \%$ と, 前期群に比して 改善傾向を認めた $(p=0.102)$. 生存における術前リスク因子の検討で, 単变量解析で有意であったのは, 前期群では, 新生児 $(p=0.036)$ ，心外型 TAPVC $(p=0.049)$, 術前肺静脈狭窄 $(P V O) （ p=0.001)$, 後 期群ではTAPVC IV型 $(p=0.001)$ であり, 多変量解析で有意であったのは, 前期群では術前 PVO（ $p=$ 0.038)，後期群ではTAPVC IV型（p=0.007）であった。 上記の心機能保護と有効肺区域の確保を重要視 した治療方針の変更により，より重症度の高い後期群においても成績が改善し，新生児や心外型 TAPVC, 術前 PVO が有意リスクから外れ，TAPVC IV型は今後の課題となった。 日心外会誌 36 巻 5 号 : 237-244 (2007)
\end{abstract}

Keywords：無脾症候群, 機能的単心室, Fontan 手術, 総肺静脈還流異常症

\section{Improving Outcomes in Right Atrial Isomerism}

Tomohiro Nakata, Akio Ikai, Yoshifumi Fujimoto, Keiichi Hirose, Noritaka Ota, Yuko Tosaka, Yujiro Ide and Kisaburo Sakamoto (Department of Cardiovascular Surgery, Shizuoka Children's Hospital, Shizuoka, Japan)

Surgery for right atrial isomerism usually has a poor outcome because of complex congenital cardiac malformations. Here we rearn the outcomes of all 71 consecutive patients with right atrial isomerism whom we treated from their initial operation at Shizuoka Children's Hospital between January 1987 and October 2006. We categorized 34 patients treated between 1987 and 1996 as the 'early' group, and 37 patients between 1997 and 2006 as the 'late' group. The early group was more commonly associated with pulmonary stenosis $(p=0.010)$, and the late group was more commonly associated with neonatal status $(p=0.010)$, body weight less than $3.0 \mathrm{~kg}$ $(p=0.037)$, and pulmonary atresia $(p=0.013)$. All 71 patients were scheduled for single ventricular repair. Survival in the early group was $52.9 \%$ at 1 year, and $32.4 \%$ at 5 years, and this poor outcome was related to 2 factors; cardiac dysfunction from volume loading and inappropriate lung perfusion area for Fontan completion. We therefore changed our surgical strategy in the late group as follows: earlier right heart bypass operation and aggressive atrioventricular valvoplasty to prevent volume overloading, and central pulmonary artery (PA) strategy (central PA plasty and blood flow source anastomosed to the central PA) and improvement of anastomosis of total anomalous pulmonary venous connection (TAPVC) to preserve appropriate lung perfusion area. If severe unbalanced pulmonary blood flow occurred, it was

2007 年 3 月 8 日受付, 2007 年 6 月 25 日採用

静岡県立こども病院心臟血管外科

干 $420-8660$ 静岡市葵区漆山 860

本論文の要旨は，第 37 回日本心臓血管外科学会学術総会

（2007 年 2 月，東京）において最優秀演題として発表した。 
treated with a novel surgical approach consisting of 'intrapulmonary-artery septation'. Survival in the late group was $66.8 \%$ at 1 year, and $53.1 \%$ at 5 years, which was better than the early group, but not with statistical significance $(p=0.102)$. Univariate analysis identified significant risk factors for mortality as neonatal status $(p=0.036)$, extracardiac TAPVC $(p=0.049)$, and preoperative pulmonary vein obstruction (PVO) $(p=0.001)$ in the early group, and mixed TAPVC $(p=0.001)$ in the late group. Multivariate analysis identified preoperative PVO ( $p=$ $0.038)$ in the early group, and mixed TAPVC $(p=0.007)$ in the late group as significant risk factors for mortality. Outcome is improving with our current strategy of preventing volume overloading and preserving an appropriate lung perfusion area, even in the late group with more severe cases, and neonatal status, extracardiac TAPVC, and preoperative PVO are no longer risk factors for mortality, but mixed type TAPVC remains a serious problem and is associated with high mortality. Jpn. J. Cardiovasc. Surg. 36 : 237-244 (2007)

表 1 患者背景

無脾症候群は多種多様な心奇形を合併し，現在でも最終 手術到達が困難なことの多い重症度の高い疾患である。こ の疾患において，対象を絞った報告は散見されるが，その 全体像を示した報告は少ない1 5)。今回，過去約 20 年間の 当科で初回より手術介入を行った連続 71 例を対象とし, 無脾症候群の全体像を明らかにすべく検討を行った。

\section{対象と方法}

1987 年から 2006 年 10 月末までの約 20 年間に静岡県立 こども病院で初回より手術介入を行った無脾症候群連続 71 例（1987～1996 年：前期群 34 例，1997 2006 年 10 月 末：後期群 37 例）を対象とし，検討を行った（follow up は 100\%)。全例 Fontan 手術対象で，二心室治療対象例 はいなかった。また，同期間中の手術非介入例は 5 例で， 適応外と判断したのが 2 例（肺高血圧を伴う主要体肺動脈 側副血行路合併例 1 例, common pulmonary vein atresia 1 例)，感染による術前死亡が 3 例であった.

初回手術介入時の日齢は，前期が $607 \pm 1,321$ （中央値 $67 ）$ 日, 後期が $52 \pm 125(23)$ 日（ $p<0.001 ）$, 体重は, 前 期が $7.4 \pm 8.1(4.1) \mathrm{kg}$, 後期が $3.6 \pm 1.7(3.2) \mathrm{kg}$ ( $p=0.002)$ と有意に後期群で初回手術介入時期が早期で あった。また，術前因子を表 1 に示すが，前期群に有意に 肺動脈弁狭窄 (PS) 例が多く $(p=0.010)$, 後期群に有 意に新生児例 $(p=0.010)$, 体重 $3.0 \mathrm{~kg}$ 末 満例 $(p=$ $0.037)$ ，肺動脈弁閉鎖（PAt）例（ $p=0.013 ）$ が多かっ た。その他の因子である高肺血流 $(\mathrm{PH})$, 心外型総肺静 脈還流異常症 (TAPVC), 肺静脈狭窄 (PVO), 2 度以上 の房室弁逆流 (AVVR), 大動脈再建が必要な大動脈縮窄 （CoA）や大動脈離断（IAA）などにおいては両群間の差 はなかった。

なお，TAPVCには術中所見などにより診断変更がな された例（とくに TAPVC IV型）が存在し，これらはす べて最終診断を記載している。また，PVOの診断は（術 前の肺血流量の多寡により診断は困難なこともあるが）心 エコー上の連続性血流の有無や平均圧較差（絶対的基準と

\begin{tabular}{lccc}
\hline & $\begin{array}{c}\text { 前期群 } \\
(n=34)\end{array}$ & $\begin{array}{c}\text { 後期群 } \\
(n=37)\end{array}$ & $p$ \\
\hline 新生児 & 9 & 21 & 0.010 \\
$\mathrm{BW}<2.5 \mathrm{~kg}$ & 2 & 5 & $\mathrm{NS}$ \\
$\mathrm{BW}<3.0 \mathrm{~kg}$ & 3 & 11 & 0.037 \\
\hline 肺動脈弃血流 & & & \\
閉鎖 (PAt) & 13 & 25 & 0.013 \\
狭窄 (PS) & 15 & 6 & 0.010 \\
肺高血圧 (PH) & 6 & 6 & $\mathrm{NS}$ \\
\hline 心外型 TAPVC & 20 & 21 & $\mathrm{NS}$ \\
Ia 型 & 1 & 3 & $\mathrm{NS}$ \\
Ib 型 & 9 & 5 & $\mathrm{NS}$ \\
III型 & 2 & 4 & $\mathrm{NS}$ \\
IV型 & 8 & 9 & $\mathrm{NS}$ \\
\hline 術前 PVO & 11 & 16 & $\mathrm{NS}$ \\
術前 AVVR $>2^{\circ}$ & 12 & 10 & $\mathrm{NS}$ \\
CoA/IAA & 3 & 1 & $\mathrm{NS}$ \\
\hline BW & & 6 & \\
\hline
\end{tabular}

BW : 体重, TAPVC : 総肺静脈還流異常症, PVO：肺静脈狭 窄, AVVR：房室弁逆流, CoA：大動脈縮窄, IAA：大動脈 離断.

しては $\geqq 8 \mathrm{mmHg}$, 形態, また, 心臓カテーテルがなさ れている場合は同じくその形態や造影遅延などにより総合 的に診断した。また，2 度以上の AVVR は術前心エコー により診断した。

\section{手術方針}

前期群の成績は不良であり，原因として，1）右心バイ パス到達までの期間が長く，そこに房室弁逆流や長期のチ アノーゼによる側副血行路増生などの問題も絡んで，容量 負荷による心機能低下を起こしたこと，また，2）肺動脈 縮窄を中心とする肺動脈系の問題, 総肺静脈還流異常を中 心とする肺静脈系の問題が絡み合って十分な有効肺区域の 確保が困難であったことが考えられ，その改善を目的に， 手術方針を後期で変更した．以下にそれらを列挙する.

\section{1. 手術時期}

初回手術時期のみならず，Glenn 手術時期も前期（ $n=$ 16）が $73.7 \pm 50.7$ (中央值 64.6）力月, 後期 $(n=25)$ 
が $9.1 \pm 5.6$ (7.6) カ月 $(p<0.001)$, Fontan 手術時期も 前期 $(n=11)$ が $109.5 \pm 37.8$ (99.6) 力月, 後期 $(n=$

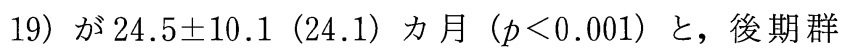
で有意に早期の手術介入を行うことで容量負荷の軽減を行 い, 現在では生後 6 力月前後での Glenn 手術, 1 歳〜 1 歳 半でのFontan 手術を行う基本方針としており，Glenn 手 術時の additional flow も基本的に残さない方針としてい る.

\section{2. 房 室 弁}

低形成や異形成を伴う房室弁が多く，容量負荷により容 易に逆流を生じるため, Glenn 手術やFontan 手術時に弁 形成を必要とすることがあるが，新生児や乳児期早期に弁 形成が必要となる重症群も一定の比率で存在する，当院で は，新生児であっても積極的に弁形成（弁尖は脆弱である ため，交連部の接合を深めるような交連部形成が中心）を 施行し，心機能の保護を目指している.

\section{Central pulmonary artery strategy (Central PA} strategy)

以前に当院から報告したと㧈り ${ }^{6,7)}$, 肺動脈縮窄 （CoPA）および肺動脈上葉枝の早期分岐を合併すること が多い無脾症候群において，従来の側開胸下でのアプロー チでは, 遺残動脈管組織の退縮に伴う中心肺動脈領域での 高度狭窄や閉塞, 肺動脈上葉枝の損傷, 側副血行路増生 などにより，姑息手術の段階で有効肺区域を損失し， Fontan 手術到達困難となった例を経験してきたため, 1993 年より行ってきた CoPA に対する積極的肺動脈形成 をさらに進め, 1997 年以降, 両側肺へのバランスのとれ た肺血流確保と，肺動脈上葉枝損傷の回避を目的として， 「胸骨正中切開下に，要すれば人工心肺を用いて十分な術 野を確保し，上中下葉枝に悪影響を残さない中心肺動脈領 域で，狭窄の原因となりうる動脈管組織を切除し，積極的 に肺動脈形成を行い，左右肺動脈に均等な血流を供給でき る手術を構築する」方針（central PA strategy）を行っ ている.

\section{TAPVC 吻合法の改良}

Fontan 手術到達に向けて修復が必要な心外型 TAPVC の解除により，とくに新生児や低体重児においては術後 PVO を起こすことを経験したため，1）可能なかぎり肺静 脈（PV）の移動変形を防ぎ（片側の PV が直径 $1 \sim 2 \mathrm{~mm}$ 程度で 4 5 本で還流している場合はそれらの剝離も行わ ずに，分枝合流部から可能なかぎり離れて吻合口を作製す る)，2）正確な運針のために必要と判断すれば循環停止も 使用し，3）心房壁が厚い場合は櫛状筋もこそぎ落として， （新生児例では） 8-0 の非吸収糸を使用して，薄いバイト で細かく縫うことで, 吻合部の厚みを小さくすることも行 い，PVO の防止に努めてきた。

\section{Intrapulmonary-artery septation (IPAS)}

上記の方針にもかかわらず，無脾症候群では CoPAを 中心とする肺動脈系の問題と, TAPVCを中心をする肺 静脈系の問題が関連して, 部分的な肺区域の血流受入れ能 力低下がおこりやすい. 当院では，片側肺血流受入れ低下 を伴う機能的単心室群に対して, 左右肺動脈の連続性を大 きく損なうことなく, 健常成長側への Glenn 吻合十能力 低下側への体肺動脈シャントを並べて再建し，これらの間 に隔壁（0.1 mm ePTFE sheet）を作製する新しい中間手 術（intrapulmonary-artery septation：IPAS）を 1998 年 より施行してきた ${ }^{8,9}$. IPAS 手術時に肺動脈形成や PVO 解除手術，また，房室弁形成なども積極的に追加し， Glenn 血流を健常成長側へ, シャント血流を能力低下側に 流し, Glennによる容量負荷軽減と, 能力低下側の成長を 促進させることで, Fontan 手術到達例を重ねてきた。

なお, central PA strategy および IPAS の術式や効果, 成績などの詳細は以前の報告を参考にされたい6 99.

\section{統計}

変数は平均值士標準偏差（中央值）の形で記載した. 2 值変数は $\chi^{2}$ 独立検定または Fisher 直接法で, 測定值は Mann-Whitney のU 検定で，2群間の検定を行った。ま た, 生存曲線は Kaplan-Meire 法により算定し, リスク因 子の検定には Cox 比例ハザードモデルを使用した。

\section{結果}

累積生存率は前期群 1 年 $52.9 \%, 5$ 年 $32.4 \%$, 後期群 1 年 $66.8 \%, 5$ 年 $53.1 \%$ であり, 後期群で改善傾向を認め た（ $p=0.102$, Log-rank). 両群におけるFontan 手術到 達への flow chart および follow up の結果を図 1 に示す. 経過中適応外となったのは, 前期群の筋ジストロフィーの 1 例のみであった。また, 前期群で退院後の遠隔死亡 （LD）が多く（判明している死因の多くが感染，不整脈， シャント不全など), 後期群で少なかった.

生存における術前リスク因子の検討を表 2 に示す。単変 量解析で有意であったのは, 全体では, 新生児 ( $p=$ $0.029)$, 心外型 TAPVC $(p=0.039)$, TAPVC IV 型 $(p<0.001)$, 術前 PVO $(p=0.004)$, 前期群では, 新生 児 $(p=0.036)$, 心外型 TAPVC $(p=0.049)$, 術前 PVO $(p=0.001)$, 後期群では TAPVC IV 型 $(p=0.001)$ のみ であった。また，これら単変量解析により $p<0.20$ の因 子をとりあげ，多変量解析で有意であったのは，全体で TAPVC IV 型 $(p=0.007)$, 前期群では術前 PVO（ $p=$

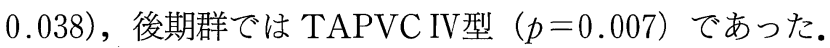
総合すると，後期群では治療方針の変更による成績改善に 伴い, さまざまな報告で無脾症候群全体や機能的単心室群 

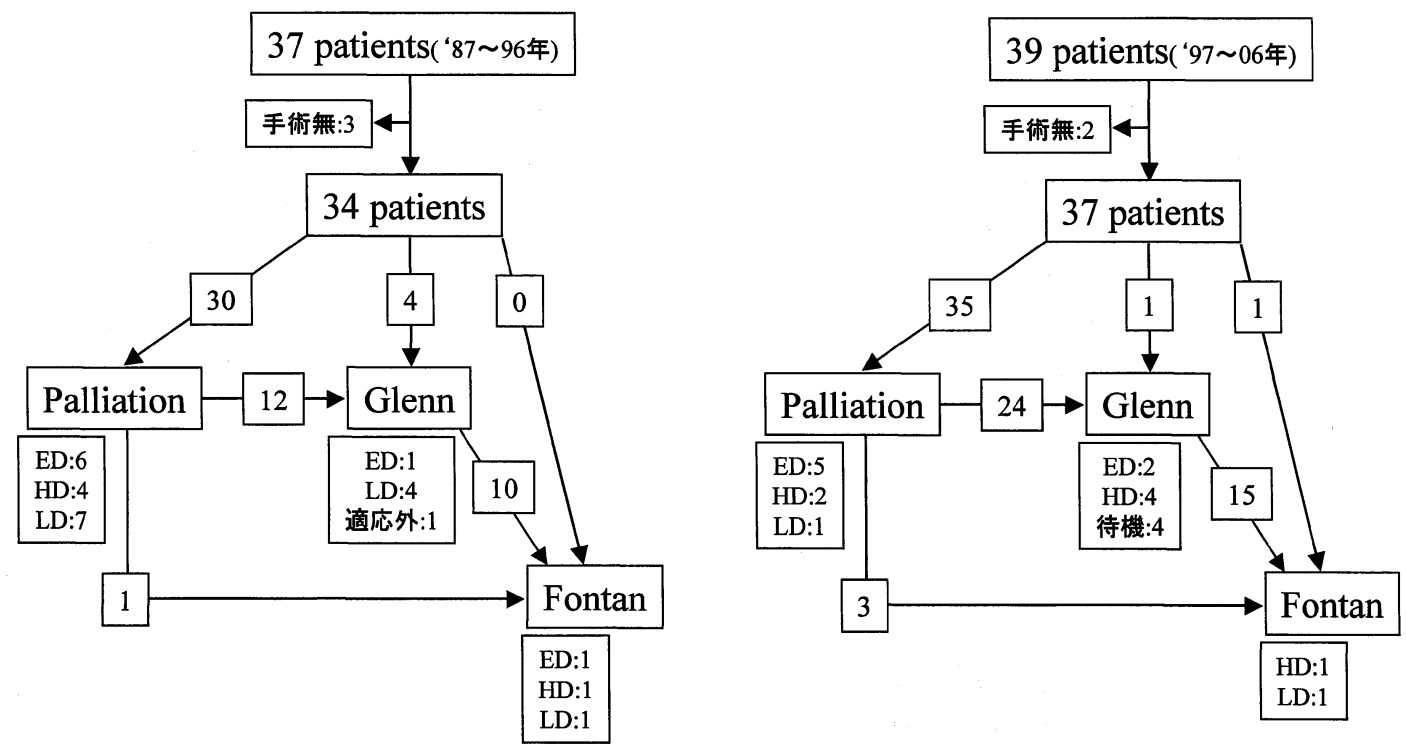

図 1 Fontan 手術への flow chart

$\mathrm{ED}$ ：早期死亡, $\mathrm{HD}$ ：病院死亡, $\mathrm{LD}$ ：遠隔死亡.

表 2 リスク因子分析（単変量解析および多変量解析）

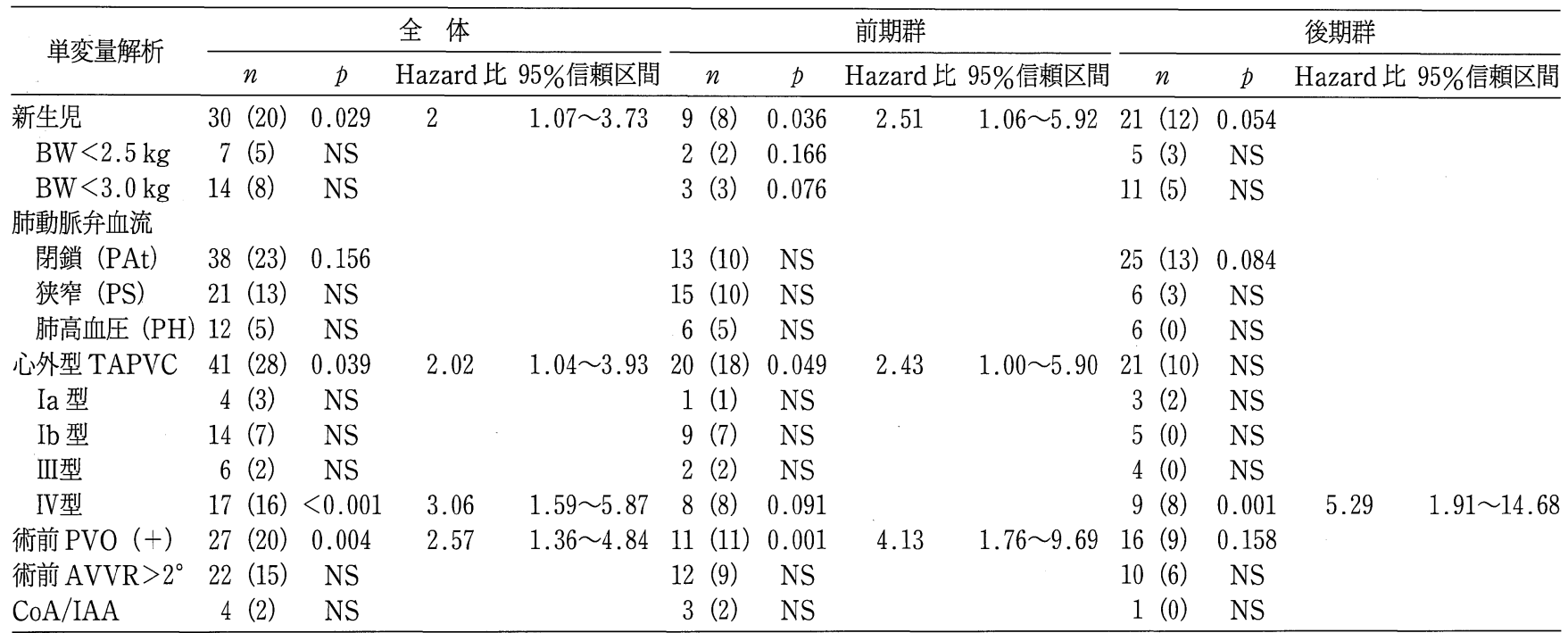

（）内は死亡例， $p$ 值は $<0.20$ のものを記載，hazard 比およびその $95 \%$ 信頼区間は $p<0.05$ のものを記載した。

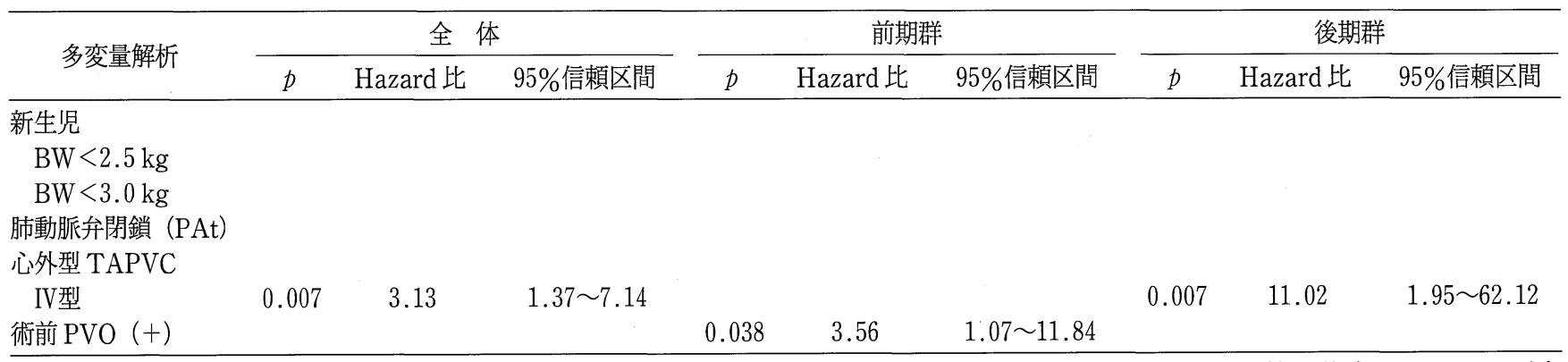

因子は単変量解析の $p<0.20$ のものを選択した. BW：体重, TAPVC：総肺静脈還流異常症, PVO：肺静脈狭窄, AVVR：房室 弁逆流, $\mathrm{CoA}$ ：大動脈縮窄, IAA：大動脈離断. 
でリスク因子とされている年, TAPVC，術前 PVO が有意リスクから外れた。

\section{1. 肺静脈 (PV)}

心外型 TAPVC 合併例の PV への手術介入は, III型（6 例）は全例初回手術時に，その他（35 例）では術前 PVO 所見の有無により決定し，初回姑息手術時に 14 例，両方 向性 Glenn 手術時に 15 例，Fontan 手術時に 2 例修復を 行った（PVOにPH を合併した例では PABのみで肺血 流の制御を行い，PVへの手術介入を初回姑息手術時に行 わなかったものが 3 例あった)。また，PVへの手術介入 前に 4 例（全例前期群）を失った。また，TAPVC II 型 に術前PVOを合併した 2 例には初回姑息手術時にPVO 解除手術を行った。

前期群では心外型 TAPVC 合併例の成績が不良で，術 前 PVO 非合併例のみが Fontan 手術に到達できた（生存 例は Ib 型の 2 例)。一方後期群では，Ib 型およびIII型で は死亡例はなく，(待機例を含めれば）全例 Fontan 手術 到達可能となり，また，術前 PVO 合併例も約半数が Fontan 手術に到達可能と, 手術方針の変更により大きく 改善を認めた。これらの成績改善により後期群で TAPVC IV型を唯一の有意なリスク因子として抽出でき た。TAPVC IV型の詳細を表 3 に示すが，Fontan 手術到 達可能となったのは，術前 PVOのない I 型十 II 型の 3 例 のみであり，術前 PVO を合併したIV型や， I 型＋I 型, I 型 + III型などの心外型 TAPVC のみで形成されたIV 型
はきわめて予後不良であった。

また，Fontan手術到達への大きな障害となる， TAPVC 修復術後の PVOは，(手術手技に伴う）吻合部

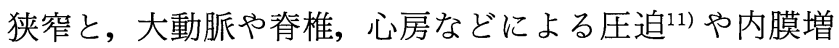
生 ${ }^{12)}$ などが原因の branch PVOに分類される. 手術手技 に伴う PVO は前期群で 3 例経験した（全例が術後初回心 エコーで診断され，全例死亡）が，後期群にはなかった。 一方, branch PVO は心エコーのみでは診断が難しいこと があり，明確に認識されるようになったのは，当院でも後 期に入ってからであった．詳細を表 4 に示すが，大半が術 前 PVO 合併例であり, 全例が後期群の症例であった. これは前期群の術前 PVO 合併例の成績がきわめて不良 (累積生存率は前期群が 6 力月 $36.4 \% ， 1$ 年 $18.2 \% ， 5$ 年 $0 \%$ ，後期群が 6 力月 $75.0 \% ， 1$ 年 $54.5 \% ， 5$ 年 $35.1 \%$ で, $p=0.013$ (Log-rank) と後期群で有意に改善）で あったことも大きく，救命率が向上して認識された合併症 であった. Branch PVOの8 例全例が, TAPVC手術介 入後の早期の心エコーで PV 血流は良好であったが，術後 5.6土5.0（1.6～14.7） カ月にその存在が診断された. 6 例で PVO解除術および stent 留置を行ったが，その結果 は不良で，3例は全 branch にいたる進行性の PVO とな り死亡した。また，PVOの原因が roof 形成であった 1 例 は（血流バランスの取れた）Fontan 手術に到達したが, 残る 2 例はIPAS を介して片肺 Fontanに到達した（1例 は脳梗塞で病院死亡（HD）となったが，Fontan 循環は

表 3 TAPVC IV型の分類

\begin{tabular}{|c|c|c|c|c|c|c|c|}
\hline & \multirow{2}{*}{ Total } & \multirow{2}{*}{ 前期群 } & \multirow{2}{*}{ 後期群 } & \multicolumn{3}{|c|}{ 最終到達 } & \multirow{2}{*}{ 生存 } \\
\hline & & & & Palliation & Glenn & Fontan & \\
\hline $\mathrm{I}+\mathrm{I}$ 型 & $4[3]$ & 1 & $3[3]$ & $3[3]$ & 1 & 0 & 0 \\
\hline I + II 型 & $7[1]$ & $4[1]$ & 3 & $2[1]$ & 2 & 3 & 1 \\
\hline I + III型 & $4[4]$ & $1[1]$ & $3[3]$ & $2[2]$ & $2[2]$ & 0 & 0 \\
\hline II + III型 & $1[1]$ & $1[1]$ & 0 & $1[1]$ & 0 & 0 & 0 \\
\hline I + II + III型 & $1[1]$ & $1[1]$ & 0 & $1[1]$ & 0 & 0 & 0 \\
\hline 合計 & 17 [10] & $8[4]$ & $9[6]$ & $9[8]$ & $5[2]$ & 3 & 1 \\
\hline
\end{tabular}

表 4 術後 branch PVO

\begin{tabular}{|c|c|c|c|c|c|c|c|c|c|c|c|}
\hline \multirow[b]{2}{*}{ 症例 } & \multirow[b]{2}{*}{ TAPVC 型 } & \multirow[b]{2}{*}{ 術前 PVO } & \multirow[b]{2}{*}{ PV 修復時期 } & \multicolumn{2}{|c|}{ PV 修復後 PVO 指摘 } & \multicolumn{5}{|c|}{ 術後 branch PVO 解除方法 } & \multirow[b]{2}{*}{ 転帰 } \\
\hline & & & & PVO 診断 & 期間（月） & 術後 PVO 部位 & 再手術 & IPAS 追加 & Stent & 最終到達 & \\
\hline 1 & IV ( Ib + III $)$ & + & Palliation 時 & 心カテ & 2.0 & 右上 branch & - & - & - & Glenn & 死亡 \\
\hline 3 & IIb & + & Palliation 時 & 心カテ & 14.7 & 右 roof 形成 & 2 回 & - & - & Fontan & 生存 \\
\hline 4 & $\mathrm{IIb}$ & + & Palliation 時 & echo & 11.8 & 右branch & 2 回 & + & - & 左片肺 Fontan & 死亡 \\
\hline 5 & $\mathrm{IV}(\mathrm{Ib}+\mathrm{IIb})$ & - & Glenn 時 & echo & 2.1 & 全branch & 2 回 & - & + & Glenn & 死亡 \\
\hline 8 & III & + & Palliation 時 & echo & 2.0 & 右下 branch 閉塞 & - & - & - & Fontan & 生存 \\
\hline
\end{tabular}

TAPVC : 総肺静脈還流異常症, PV : 肺静脈, PVO : 肺静脈狭窄, IPAS : intrapulmonary-artery septation. 
成立した)。

\section{2. 房室弁逆流 (AVVR)}

房室弁に対する手術介入は, 23 人（再形成, 再々形成 を含む, のべ弁形成が 28 回, 弁置換が 3 回）であり, 詳 細を表 5 に示すが, Fontan 手術後の形成や置換例はな かった。初回術前 2 度以上の AVVR と, 2 度未満で分類 すると，2 度以上でも形成を必要としないままFontan 手 術到達例がある反面, 2 度未満でも初回姑息手術後に逆流 が増悪し，その後，弁形成を必要とする例が約 2 割存在し ていた。 Glenn 手術後は容量負荷がとれることもあり，大 きく増悪する例は少ないが，容量負荷がかかりやすい Glenn 手術までの綿密な観察と, 必要に応じて積極的な弁 形成を行うことが重要と思われた。また，前期では弁への 手術介入時期を逸して，初回姑息術後に死亡した例を多く 認めたが，後期群では新生児期からでも積極的に手術介入 を行い（初回姑息術時の弁形成後死亡した 3 例はすべて進 行性 PVO による死亡例であった), 一定の症例が Fontan 手術に到達可能となった。

\section{Fontan 到達例}

今回の対象で Fontan 手術に到達した 30 例において, 早期死亡（ED） 1 例, HD 2 例, LD 2 例（1 例は PVO, 他例は感染) を認め, 累積生存率は 1 年, 5 年ともに $81.5 \%$ であり，1 年以上経過した LD はなかった. 再手術 例は，開心術が，PVO 解除 1 例，fenestration 作製 2 例，

表 5 房室弁逆流に対する弁形成術

\begin{tabular}{|c|c|c|c|c|c|c|}
\hline \multirow{2}{*}{ 弁形成 } & \multirow{2}{*}{$n$} & \multicolumn{2}{|c|}{ 再手術介入 } & \multicolumn{3}{|c|}{ 最終到達 } \\
\hline & & 再形成 & 弁置換 & Palliation & Glenn & Fontan \\
\hline Palliation 時 & 4 & 1 & 1 & $1(1)$ & $2(2)$ & $1(0)$ \\
\hline Palliation 後 & 1 & & & $1(1)$ & - & - \\
\hline Glenn 時 & 14 & 3 & 2 & - & $7(5)$ & $7(2)$ \\
\hline Glenn 後 & 2 & & & - & 1 (1) & $1(0)$ \\
\hline Fontan 時 & 2 & & & - & - & $2(0)$ \\
\hline 計 & 23 & 4 & 3 & $2(2)$ & $10(8)$ & $11(2)$ \\
\hline \multicolumn{7}{|c|}{ （）内は死亡例. } \\
\hline \multirow{2}{*}{\multicolumn{3}{|c|}{ 術前 AVVR }} & \multicolumn{2}{|c|}{$\mathrm{AVVR} \geqq 2^{\circ}$} & \multicolumn{2}{|c|}{$\mathrm{AVVR}<2^{\circ}$} \\
\hline & & & 前期 & 後期 & 前期 & 後期 \\
\hline \multirow{2}{*}{\multicolumn{3}{|c|}{$\begin{array}{l}\text { 初回 palliation 時 plasty } \\
\text { 初回 Glenn 時 plasty } \\
\text { 初回手術以降 }\end{array}$}} & & $4(3)$ & & \\
\hline & & & $2(2)$ & $1(1)$ & & \\
\hline \multicolumn{3}{|c|}{ Palliation 後 plasty } & & & & $1(1)$ \\
\hline \multicolumn{3}{|c|}{ Glenn 時 plasty } & 1 (1) & $1(0)$ & $4(2)$ & $5(1)$ \\
\hline \multicolumn{3}{|c|}{ Glenn 後 plasty } & & 1 (1) & & $1(0)$ \\
\hline \multicolumn{3}{|c|}{ Fontan 時 plasty } & $1(0)$ & $1(0)$ & & \\
\hline \multicolumn{3}{|c|}{ Plasty 不要 } & $2(0)$ & $1(0)$ & $7(3)$ & $15(3)$ \\
\hline \multicolumn{3}{|c|}{ Palliation のみ } & $6(6)$ & $1(1)$ & $11(11)$ & $5(5)$ \\
\hline \multicolumn{3}{|c|}{ 計 } & $12(9)$ & $10(6)$ & $22(16)$ & $27(10)$ \\
\hline
\end{tabular}

（ ）内は死亡例. AVVR：房室弁逆流.
流出路狭窄解除 1 例，その他がペースメーカー植込み 1 例, 体肺動脈側副血行路処理 1 例, 大腿動静脈㾞修復 1 例 であった. Fontan 手術後心カテーテル検査は 21 例（片 肺Fontan 手術後 1 例を含む) になされ，体静脈圧 $12.4 \pm 2.5 \mathrm{mmHg}$, 駆出率 $56.6 \pm 11.7 \%$, 心係数 $3.0 \pm$ $0.9 \mathrm{l} /$ 分 $/ \mathrm{m}^{2}$ ，酸素飽和度 $94.3 \pm 1.3 \%$ と良好であった。

\section{考察}

今回の対象 71 例のおもな心奇形の頻度は，他の報告と の比較で ${ }^{-5)}$, PAt 例が多く, PS 例が少ない（とくに後 期群）傾向があり，TAPVC IV 型の頻度は最も高く，当 院の母集団は適応外症例が少ないことで，より無脾症候群 の全体像に近い可能性があると思われた，累積生存率は全 体で 1 年 $60.1 \% ， 5$ 年 $41.5 \% ， 10$ 年 $39.3 \%$ であり，より 手術介入時期が低年齢化し，PAt 例が多く，母集団が重 症化した後期群においても，さまざまな治療方針の変更に より，1 年 $66.8 \% ， 5$ 年 $53.1 \%$ と改善した.

PVにおいて, 単心室や房室錯位に合併した TAPVC の報告では ${ }^{13 \sim 15)}$ ，生命リスクとして，PV に対する解除時 期，PAt例および初回シャント例などをあげており，ま たTAPVCの型による検討では，二心室群において

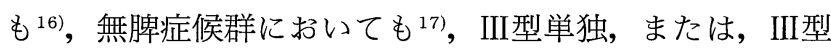
またはIV型，術前 PVO を生命リスクにあげるものはある が，TAPVC IV型を単独で生命リスクだとするものは， 調べたかぎりではなかった。また，Fontan 手術に到達し た房室錯位の報告では，心外型 TAPVC 合併は I 型のみ であるという報告もみられる18,19). TAPVC のなかでIV型 は，さまざまな報告を合わせると，約 10\%弱と考えられ るが20 22), 当院では無脾症候群に合併した TAPVC の型 による手術適応制限はなく, 術中や初期救命後の心臓力 テーテルなどでIV型が最終診断とされることもあり, TAPVC IV型の割合がきわめて高く，この症例数および 先述した全体の成績の改善が TAPVC IV型の生命リスク を明らかにしたと思われる（なお，後期群でTAPVC IV 型を除くと累積生存率は 1 年 $81.8 \%, 5$ 年 $67.7 \%$ あっ た)、TAPVC IV 型は，さまざまな variationがあ $\eta^{20,21)}$ ，二心室群であれば， 3 本までが共通肺静脈に還流 する場合は，その交通を確立すれば良く，マイナーな残り の 1 本の PV を放置しても良いと考元られてる。一方， 機能的単心室群ではすべての再建が必要であり，また，肺 血流の多寡が存在することで共通肺静脈も小さく1)，ま た，肺静脈血が分離することでそれぞれの共通肺静脈がよ り小さくなるために，依然として救命困難になっていると 思われる。

また, 術後 branch PVO は, 大半が術前 PVO 合併例で 生じており, 二心室群でさえも, 両側の ostial PVO は予 
後不良であるとの報告 ${ }^{12)}$ があり, 現在も Fontan 手術到達 に向けた大きな障害である. 術後のPVOに対して, sutureless 法の優位性を示す報告 ${ }^{23)}$ があり，自験例におい ても，症例 4， 7 の 2 例において sutureless 法を施行した が, 機能的単心室群に対するこの術式の PVO 解除効果に は疑問が残った。また，新生児期にPVOを合併した TAPVCに対して，その型にかかわらず，初回手術から sutureless 法を行うことで成績改善を目指しているとの報 告 ${ }^{17)} も$ あ, 興味深い. 自験例では, branch PVOの全 分枝への進行例や, TAPVC IV 型合併例は救命困難で あったが, branch PVO が片側のみであれば, IPASを介 して，健常成長側の肺の能力を評価し，また，側副血行路 などの過剰な容量負荷を回避することで，(PVO 側の肺の rescue は困難であったが）片肺 Fontan 手術を施行するこ とが可能であった。また，branch PVO が起こりうること を念頭におる, central PA strategyにより, 有効肺区域 を確保することも重要である。

また, 前期群と比較して, 後期群においては, PH, PS 例の成績が安定し, 有意差にはいたらなかったが, PAt 例の生命リスクの高いことが示唆された。新生児期手術介 入例の多くが術前 PVO または PAt 群が占め, 新生児例 が生命リスクであるとの報告3)もあり，また，TAPVC 合 併例に限定しても，PAt 例が生命リスクであるとする報 告 ${ }^{15)} も$ 存在した.

また，今回の検討では有意リスクとならなかったが，術 前 AVVR をあげる報告もある ${ }^{1)}$. 他の報告で機能的単心 室の有意な弁逆流は, Glenn 手術による容量負荷軽減のみ で改善する例は $22 \%$ 程度で，(房室錯位の房室弁にしばし ば認める) dysplastic な弁には改善例がないとしてお $\eta^{24)}$, 無脾症候群に対しては積極的な弁形成による心機能 保護と Glenn 手術までの綿密な観察が重要であると思わ れた。

また，無脾症候群や房室錯位の Fontan 到達例の予後は 比較的良好であるとの報告を認め ${ }^{18,19,25)}$, 自験例において も心機能は良好に保たれていた。合併病変に対する積極的 な手術介入も, 術後の再手術が少ない要因と思われる.

以上，さまざまな視点から無脾症候群のリスク因子，問 題点を検討した。手術成績が安定した現在においても, TAPVC IV型は今後の課題として残った.

\section{結語}

有効肺区域の確保と心機能保護を目的としたさまざまな 治療方針の改良により, 無脾症候群の治療は確実に前進し ている.TAPVC IV型は今後の課題である.

\section{文献}

1) Hashmi, A., Abu-Sulaiman, R., McCrindle, B. W. et al. : Management and outcomes of right atrial isomerism : a 26-year experience. J. Am. Coll. Cardiol. 31 : 1120-1126, 1998.

2) Sinzobahamvya, N., Arenz, C., Brecher, A. M. et al. : Atrial isomerism: a surgical experience. Cardiovasc. Surg. 7 : 436-442, 1999.

3) Sadiq, M., Stumper, O., De Giovanni, J. V. et al. : Management and outcome of infants and children with right atrial isomerism. Heart 75: 314-319, 1996.

4) Cheung, Y. F., Cheng, V. Y., Chau, A. K. et al. : Outcome of infants with right atrial isomerism: is prognosis better with normal pulmonary venous drainage? Heart 87 : 146-152, 2002.

5）神崎 歩, 里見元義, 安河内聰ほか：無脾症候群の長期予後 の検討. 日小循誌 19: 542-549, 2003.

6）藤本欣史, 猪飼秋夫, 太田教隆注か：肺動脈縮窄を伴う無脾 症候群に対する新生児期, 乳児期早期の肺動脈形成は Fontan 到達に寄与するのか? 一肺動脈分枝の成長に関す る検討一. 日小循誌 $22: 80-86,2006$.

7）坂本喜三郎, 小野安生：無脾症候群に対する治療戦略. 小児 科診療 113: 289-296, 2007.

8）坂本喜三郎, 西岡雅彦, 藤本欣史ほか：片肺肺血管系に問題 をもつ完全右心バイパス術困難例に対する新しい中間手 術一intrapulmonary septation technic. 胸部外科 56 : 316 $322,2003$.

9) Sakamoto, K., Ikai, A., Fujimoto, Y. et al. : Novel surgical approach 'intrapulmonary-artery septation' for Fontan candidates with unilateral pulmonary arterial hypoplasia or pulmonary venous obstruction. Interact. Cardiovasc. Thorac. Surg. 6 : 150-154, 2007.

10) Lee, J. R., Choi, J. S., Kang, C. H. et al. : Surgical results of patients with a functional single ventricle. Eur. J. Cardio-thorac. Surg. 24: 716-722, 2003.

11) O'Donnell, C. P., Lock, J. E., Powell, A. J. et al. : Compression of pulmonary veins between the left atrium and the descending aorta. Am. J. Cardiol. 91 : 248-251, 2003.

12) Lacour-Gayet, F., Zogghbi, J., Serraf, A. E. et al. : Surgical management of progressive pulmonary venous obstruction after repair of total anomalous pulmonary venous connection. J. Thorac. Cardiovasc. Surg. 117: 679-687, 1999.

13) Gaynor, J. W., Collins, M. H., Rychik, J. et al. : Longterm outcome of infants with single ventricle and total anomalous pulmonary venous connection. J. Thorac. Cardiovasc. Surg. 117 : 506-514, 1999.

14) Lodge, A. J., Rychik, J., Nicolson, S. C. et al. : Improving outcomes in functional single ventricle and total anomalous pulmonary venous connection. Ann. Thorac. Surg. 78 : 1688-1695, 2004.

15) Morales, D. L., Braud, B. E., Booth, J. H. et al. : Heterotaxy patients with total anomalous pulmonary venous return: improving surgical results. Ann. Thorac. Surg. 82 : 1621-1628, 2006.

16) Ricci, M., Elliott, M., Cohen, G. A. et al. : Management of pulmonary venous obstruction after correction of TAPVC: risk factors for adverse outcome. Eur. J. Cardio-thorac. Surg. 24: 28-36, 2003.

17) Yun, T. J., Al-Radi, O. O., Adatia, I. et al. : Contemporary management of right atrial isomerism : effect of evolving therapeutic strategies. J. Thorac. Cardiovasc. Surg. 131 : 1108-1113, 2006. 
18) Kim, S. J., Kim, W. H., Lim, H. G. et al. : Improving results of the Fontan procedures in patients with heterotaxy syndrome. Ann. Thorac. Surg. 82 : 1245-1251, 2006.

19) Stamm, C., Friehs, I., Duebener, L. F. et al. : Improving results of the modified Fontan operation in patients with heterotaxy syndrome. Ann. Thorac. Surg. 74 : 1967-1978, 2002.

20) Delius, R. E., de Leval, M. R., Elliott, M. J. et al. : Mixed total pulmonary venous drainage: still a surgical challenge. J. Thorac. Cardiovasc. Surg. 112 : 1581-1588, 1996.

21) Imoto, Y., Kado, H., Asou, T. et al. : Mixed type of total anomalous pulmonary venous connection. Ann. Thorac. Surg. 66 : 1394-1397, 1998.

22) Mavroudis, C., Gevitz, M., Ring, W. S. et al. : The Society of Thoracic Surgeons National Congenital Heart
Surgery database report: analysis of the first harvest (1994-1997). Ann. Thorac. Surg. 68 : 601-624, 1999.

23) Lacour-Gayet, F.: Surgery for pulmonary venous obstruction after repair of total anomalous pulmonary venous return. Semin. Thorac. Cardiovasc. Surg. Pediatr. Card. Surg. Ann. 9: 45-50, 2006.

24) Mahle, W. T., Cohen, M.S., Spray, T. L. et al.: Atrioventricular valve regurgitation in patients with single ventricle: impact of the bidirectional cavopulmonary anastomosis. Ann. Thorac. Surg. 72: 831-835, 2001.

25) Azakie, A., Merklinger, S. L., Williams, W. G. et al : Improving outcomes of the Fontan operation in children with atrial isomerism and heterotaxy syndromes. Ann. Thorac. Surg. 72: 1636-1640, 2001. 